\section{Paclobutrazol Bioassay Using the Axillary Growth of a Grape Shoot}

\author{
David M. Hunter \\ Agriculture Canada Research Branch, Research Station, Harrow, Ont. \\ NOR 1GO, Canada
}

\author{
John T.A. Proctor \\ Department of Horticultural Science, University of Guelph, Guelph, Ont. \\ N1G 2W1, Canada
}

Additional index words. growth inhibitor, growth retardant, PP333, Vitis spp.

\begin{abstract}
A system was developed to evaluate the response of grapes (Vitis spp. 'Seyval') to soil-applied paclobutrazol. The youngest fully expanded leaf, and its axillary bud, on single shoots 6 to 9 nodes long developing on rooted softwood cuttings, were retained for use in a bioassay. The shoot that developed from the axillary bud exhibited a dosage-dependent growth inhibition following soil applications of paclobutrazol at 4 dosages between 1 and $1000 \mu \mathrm{g} \cdot \mathrm{g}^{-1}$ soil. Other aerial components showed no response to paclobutrazol. This test plant system has potential for use in physiological studies with soil-applied plant growth regulators. Chemical name used: $\beta-[$ (4-chlorophenyl)methyl]- $\alpha$-(1,1-dimethylethyl)1H-1,2,4-triazole-1-ethanol

(paclobutrazol)
\end{abstract}

$\beta$-[(4-Chlorophenyl)methyl]- $\alpha$-(1,1,-dimethylethyl)- 1H-1,2,4-triazole-1-ethanol (paclobutrazol) retards growth in many plant species, including grapes (Clingeleffer, 1985; Intrieri et al., 1986; Reynolds, 1988a). Following foliar applications of paclobutrazol to duction in shoot growth and leaf area that was "nearly proportional to the applied concentration." With trunk applications, Ahmedullah et al. (1986) and Reynolds (1988b) observed linear inhibitory effects of increasing paclobutrazol dose on shoot growth. However, the growth response of various vegetative growth components to paclobutrazol dosages has not been well-characterized in grape; and we found no paclobutrazol bioassays using grapevines. A test plant system used for investigating growth and physiological responses of grapevines to soil applications of paclobutrazol was therefore developed as a paclobutrazol bioassay.

Single-node green shoot cuttings of virusfree 'Seyval' grapevines were rooted in a mist bench for $\approx 3$ weeks, transplanted into 0.8-liter plastic pots containing about $250 \mathrm{~g}$ air dry weight of a 1 peat : 1 perlite : 1 sandy loam soil mix (by volume), and grown in a 25/20C (day/night) greenhouse. A single shoot was allowed to develop. When the shoot reached the 6- to 9-leaf stage, it was decapitated just above the node subtending the most recently fully expanded leaf (usually node 3 to 5 from the base), care being taken not to damage the axillary bud at this node. All lower leaves, petioles, and axillary buds were

Received for publication 30 Nov. 1988. We gratefully acknowledge the gift of paclobutrazol from Chipman, Inc. The cost of publishing this paper was defrayed in part by the payment of page charges. Under postal regulations, this paper therefore must be hereby marked advertisement solely to indicate this fact. grapevines, Intrieri et al. (1986) noted a re- carefully removed. Thus, the experimental plant unit consisted of a single leaf, its petiole and axillary bud, the stem, and the roots (Fig. 1).

When the retained axillary bud began to develop into a leafy shoot, paclobutrazol (250 $\mathrm{g} \cdot$ liter flowable) was applied as a soil drench in $50 \mathrm{ml}$ of water to provide $0,1,10,100$, or $1000 \mu \mathrm{g}$ a.i/g soil mix. After treatment, plants were grown either in a greenhouse or a growth chamber, both of which were maintained at 25/20C (day/night), a 16-hr photoperiod, and a minimum photosynthetic photon flux density of $500 \mu \mathrm{mol} \cdot \mathrm{s}^{-1} \cdot \mathrm{m}^{-2}$ at the level of the retained leaf. Plants were watered daily as required, and every 3 days were provided with a dilute $20 \mathrm{~N}-20 \mathrm{P}-20 \mathrm{~K}$ fertilizer solution. Plants harvested on day 15 after paclobutrazol application were divided into the following components: the original retained leaf, the stem (including the original leaf petiole), the roots (separated from the main shoot at the level of the uppermost lateral root, and the axillary shoot. Leaf areas were measured using a LI-COR LI-3000 (Lincoln, Neb.) leaf area meter. Fresh weights were determined immediately following harvest, and the plant components were dried under vacuum at $60 \mathrm{C}$ for $24 \mathrm{hr}$ before dry weight determinations. Data were subjected to regression analysis, and significant differences between treatments are reported at the 5\% level following single-degree-offreedom contrasts (Snedecor and Cochran, 1980).

Growth responses to paclobutrazol application were noticeable by 7 days after treatment. Axillary shoots of treated plants were shorter, and leaves developing on these axillary shoots were darker green and smaller than for control plants. By 15 days after treatment, differences in axillary growth were more pronounced, particularly at the higher paclobutrazol doses (Table 1). The reduction in axillary shoot growth, as determined by shoot length, was $>30 \%$ at the $1 \mu \mathrm{g} \cdot \mathrm{g}$ dose and $\geq 70 \%$ at the higher dosages of paclobutrazol, resulting in a rosetted appearance. Paclobutrazol had similar effects on fresh and dry weight. Leaf number, which tended to be reduced in the greenhouse experiment, was reduced by up to $40 \%$ in the growth chamber experiment (Table 1). In both experiments, paclobutrazol application induced a much greater reduction in leaf area than in leaf number. These observations, i.e., a slight reduction in axillary leaf number and a large reduction in axillary leaf area, are consistent with earlier reports that inhibitors of gibberellin biosynthesis have a greater effect on cell expansion than on cell division at the shoot apex (Britz and Saftner, 1987; Nitsche et al., 1985). Leaves on the axillary shoot also exhibited a downward curling of the leaf margins and thickened appearance that has been described previously for other plant species (Jaggard et al., 1982; Steffens et al., 1985). In both greenhouse- and growth chamber-grown plants, the specific leaf weight
Table 1. Axillary shoot data for greenhouse- and growth chamber-grown 'Seyval' grape plants harvested 15 days after treatment with paclobutrazol.

\begin{tabular}{|c|c|c|c|c|c|}
\hline \multirow{2}{*}{$\begin{array}{l}\text { Plant } \\
\text { component }\end{array}$} & \multicolumn{5}{|c|}{ Paclobutrazol $\left(\mu \mathrm{g} \cdot \mathrm{g}^{-1}\right.$ soil $)$} \\
\hline & Control & 1 & 10 & 100 & 1000 \\
\hline \multicolumn{6}{|c|}{ Greenhouse-grown plants } \\
\hline Fresh weight (g) & $1.83 \mathrm{a}^{2}$ & $1.48 \mathrm{~b}$ & $1.14 \mathrm{~b}$ & $0.65 \mathrm{c}$ & $0.56 \mathrm{c}$ \\
\hline Dry weight $(\mathrm{g})$ & $0.35 \mathrm{a}$ & $0.30 \mathrm{~b}$ & $0.25 \mathrm{~b}$ & $0.14 \mathrm{c}$ & $0.12 \mathrm{c}$ \\
\hline Leaf number & $5.7 \mathrm{a}$ & $5.8 \mathrm{a}$ & $5.2 \mathrm{a}$ & $4.9 \mathrm{a}$ & $5.1 \mathrm{a}$ \\
\hline Leaf fresh weight $(\mathrm{g})$ & $1.32 \mathrm{a}$ & $1.04 \mathrm{~b}$ & $0.82 \mathrm{~b}$ & $0.49 \mathrm{c}$ & $0.43 \mathrm{c}$ \\
\hline Leaf area $\left(\mathrm{cm}^{2}\right)$ & $93.2 \mathrm{a}$ & $67.7 \mathrm{~b}$ & $49.8 \mathrm{c}$ & $27.4 \mathrm{~d}$ & $21.9 \mathrm{~d}$ \\
\hline SLW (mg fresh weight $/ \mathrm{cm}^{2}$ ) & $14.18 \mathrm{e}$ & $15.34 \mathrm{~d}$ & $16.66 \mathrm{c}$ & $17.93 \mathrm{~b}$ & $19.55 \mathrm{a}$ \\
\hline \multicolumn{6}{|c|}{ Growth chamber-grown plants } \\
\hline Fresh weight (g) & $3.26 \mathrm{a}$ & $2.42 \mathrm{~b}$ & $0.98 \mathrm{c}$ & $0.94 \mathrm{c}$ & $0.53 \mathrm{~d}$ \\
\hline Dry weight $(\mathrm{g})$ & $0.70 \mathrm{a}$ & $0.56 \mathrm{~b}$ & $0.24 \mathrm{c}$ & $0.22 \mathrm{c}$ & $0.13 \mathrm{~d}$ \\
\hline Leaf number & $7.9 \mathrm{a}$ & $8.0 \mathrm{a}$ & $6.2 \mathrm{~b}$ & $6.7 \mathrm{~b}$ & $4.4 \mathrm{c}$ \\
\hline Leaf fresh weight $(\mathrm{g})$ & $2.20 \mathrm{a}$ & $1.64 \mathrm{~b}$ & $0.71 \mathrm{c}$ & $0.67 \mathrm{c}$ & $0.39 \mathrm{~d}$ \\
\hline Leaf area (cm') & $145.1 \mathrm{a}$ & $98.5 \mathrm{~b}$ & $37.2 \mathrm{c}$ & $31.4 \mathrm{~cd}$ & $17.4 \mathrm{~d}$ \\
\hline SLW (mg fresh weight $\left./ \mathrm{cm}^{2}\right)$ & $15.35 \mathrm{e}$ & $17.17 \mathrm{~d}$ & $20.75 \mathrm{c}$ & $23.99 \mathrm{~b}$ & $28.31 \mathrm{a}$ \\
\hline Length $(\mathrm{mm})$ & $167 \mathrm{a}$ & $109 \mathrm{~b}$ & $41 \mathrm{c}$ & $47 \mathrm{c}$ & $28 \mathrm{~d}$ \\
\hline
\end{tabular}

${ }^{2}$ Means in the same row followed by the same letter are not significantly different $(P=0.05)$ by singledegree-of-freedom contrasts. 


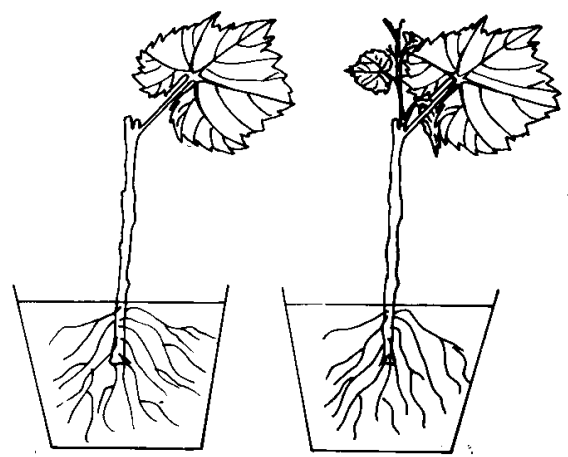

Fig. 1. Model plant system using growth of the axillary shoot for paclobutrazol bioassay. (left) one-leaf stage (day 0), (right) with axillary growth (day 15).

(SLW) of axillary leaves increased linearly in response to log-scale increases in paclobutrazol dose (Table 1).

These growth responses observed in a simple plant system are similar to those reported for intact plants of grapes (Intrieri et al., 1986; Clingeleffer, 1985). While other variables measured had significant quadratic, as well as linear, responses to logscale increases in paclobutrazol dosage, the increase in SLW of the axillary leaves had only a linear response in both greenhouse and growth chamber studies and, therefore, has more potential for use as a bioassay.

The simplified plant system reported here consists of a single source leaf, a dynamic sink (the developing axillary shoot), and two weaker sinks (the stem and the roots). The system has potential for rapid studies to investigate early effects of paclobutrazol on photosynthesis and the partitioning of photoassimilates. The system also has potential for use in similar investigations of soil-applied growth regulating compounds.

\section{Literature Cited}

Ahmedullah, M., A. Kawakami, C.R. Sandidge, III, and R.L. Wample. 1986. Effect of paclobutrazol on the vegetative growth, yield, quality, and winter hardiness of buds of 'Concord' grape. HortScience 21:273-274.

Britz, S.J. and R.A. Saftner. 1987. Inhibition of growth by ancymidol and tetcyclacis in the gibberellin-deficient Dwarf-5 mutant of Zea mays L. and its prevention by exogenous gibberellin. J. Plant Growth Regulat. 6:215-219.

Clingeleffer, P.R. 1985. Use of plant growth regulating chemicals in viticulture. Chemicals in the vineyard. Austral. Soc. of Viticulture and Oenology, Inc., Mildura. p. 95-100.

Intrieri, C., O. Silvestroni, and S. Poni. 1986. Preliminary experiments on paclobutrazol effects on potted grapevines (V. vinifera, $c v$. Trebbiano). Acta Hort. 179:589-592.

Jaggard, K.W., D.K. Lawrence, and P.V. Biscoe. 1982. An understanding of crop physiology in assessing a plant growth regulator on sugar beets. p. 139-150. In: J.S. McLaren (ed.). Chemical manipulation of crop growth and development. Butterworths, London.

Nitsche, K., K. Grossman, E. Sauerbrey, and J. Jung. 1985. Influence of the growth retardant tetcyclacis on cell division and cell elongation in plants and cell cultures of sunflower, soybean, and maize. J. Plant Physiol. 118:209 218.

Reynolds, A.G. 1988a. Inhibition of lateral shoot growth in summer-hedged 'Riesling' grapevines by paclobutrazol. HortScience 23:728-730.

Reynolds, A.G. 1988b. Effectiveness of NAA and paclobutrazol for control of regrowth of trunk suckers on 'Okanagan Riesling' grapevines. J.
Amer. Soc. Hort. Sci. 113:484-488.

Snedecor, G.W. and W.G. Cochran. 1980. Statistical methods. 7th ed. Iowa State Univ. Press, Ames. p. 224-226.

Steffens, G.L., J.K. Byun, and S.Y. Wang. 1985. Controlling plant growth via the gibberellin biosynthesis system. I. Growth parameter alterations in apple seedlings. Physiol. Plant. 63:163168. 